\title{
Continental Shelf Delimitation Beyond 200 Nautical Miles: Approaches Taken by Coastal States before the Commission on the Limits of the Continental Shelf
}

\author{
COALTER LATHROP
}

\section{INTRODUCTION}

In the introductory note to Volume $\mathrm{V}$ of this series, David Colson wrote that "the promotion and resolution of claims to the outer continental shelf beyond 200 n.m. from the coast - a feature of maritime delimitation now in its infancy - is likely to become an important component of many maritime boundary negotiations that are waiting in the wings." ${ }^{1}$ David Anderson made note in the same volume that " $\mathrm{t}]$ he delimitation, as between neighboring states, of the continental shelf beyond 200 n.m. is a topic that will doubtless receive greater attention as the work of the Commission gathers momentum." In the five years since the publication of Volume V, the work of the Commission on the Limits of the Continental Shelf (the CLCS or the Commission) has indeed gathered momentum and delimitation of the continental shelf beyond 200 n.m. from the coast has started to take shape, primarily through the implicit promotion of claims embedded in submissions to the Commission and, to a lesser extent, the resolution by agreement of overlapping claims to extended continental shelf. ${ }^{3}$ Because there is, as yet, so little State practice in the actual delimitation of the extended continental shelf, this essay focuses on the CLCS submission process and the place of boundary delimitation in that process.

In the extended continental shelf game, States have two goals: (1) to maximize, bolster and protect their claims to extended continental shelf

1 David A. Colson, Introduction, in V International Maritime Boundaries xxvii, xxx (David A. Colson \& Robert W. Smith eds., 2005).

2 David Anderson, Developments in Maritime Boundary Law and Practice, in V International Maritime Boundaries 3199, 3215 (David A. Colson \& Robert W. Smith eds., 2005).

3 The term "extended continental shelf" is used here to indicate those areas of seabed and subsoil of the continental shelf, slope and rise located beyond 200 n.m. from the baseline. The term "outer continental shelf" is often used to refer to these same areas, but should be distinguished from the same term as it is used in United States statutory language and which refers to the continental shelf beginning at the outer limit of each federated states' submerged lands (usually 3 n.m. from shore) and extending to the outer limit of federal jurisdiction. See Outer Continental Shelf Lands Act, 43 U.S.C. $\$ 1301$. 
with respect to both the delineation of outer limits and the delimitation of shelf boundaries with opposite or adjacent States, and (2) to receive the Commission's imprimatur on their outer limit claim made pursuant to Article 76. In some circumstances these two goals are in tension. This essay examines the intersection between delimitation and delineation of the continental shelf through the lens of submissions made to the Commission and focuses on the approaches submitting States have taken to reduce the tension created by delimitation issues embedded in those submissions.

It should be emphasized at the start that bilateral delimitation of the continental shelf between opposite or adjacent coastal States is a distinct and wholly separate process from the unilateral delineation and establishment of the outer limits of the continental shelf beyond 200 n.m. from shore on the basis of Commission recommendations: the former requires agreement between two or more States on the division of areas encompassed by overlapping continental shelf claims, the latter requires individual coastal States to comply with the substantive and procedural terms of Article 76 of the 1982 United Nations Convention on the Law of the Sea (UNCLOS or the Convention). While these two processes-boundary delimitation and outer limit delineation - are separate, the issues involved are often closely linked. And, although efforts have been made to insulate the Article 76 delineation process from related delimitation disputes, most submissions lodged with the CLCS implicate one or more boundary relationships.

A brief overview is provided in Part II. The submission process, the role of the Commission on the Limits of the Continental Shelf, and the attempt to separate bilateral delimitation issues from the Commission delineation process is described in more detail in Part III. The approaches taken by States to address delimitation issues embedded in extended shelf claims are described in Part IV. Part V contains some concluding remarks.

\section{OVERVIEW}

The Commission on the Limits of the Continental Shelf is an international treaty body formed pursuant to Annex II of UNCLOS and composed of 21 experts in the fields of geology, geophysics or hydrography. ${ }^{4}$ The first members of the Commission were elected in March 1997, the Commission adopted its initial rules in June 1997, and the Commission's Scientific and 
Technical Guidelines were adopted in May 1999. The Commission received its first submission, from the Russian Federation, in December 2001. The primary function of the Commission is "to consider the data and other material submitted by coastal States concerning the outer limits of the continental shelf in areas where those limits extend beyond 200 nautical miles, and to make recommendations in accordance with article 76." ${ }^{5}$ It is then for the coastal State to establish its continental shelf outer limit on the basis of those recommendations. ${ }^{6}$

As predicted, the work of the Commission has indeed gathered momentum. During the first ten years of the Commission's existence coastal States made only 11 submissions. In the 12 months leading up to the May 2009 deadline for many States, 40 additional submissions were lodged. ${ }^{7}$ At the time of writing, 51 submissions have been made to the Commission with an additional 45 submissions of preliminary information documents which function - essentially - as placeholders for future submissions. ${ }^{8}$ In total, 74 coastal States have either lodged submissions or indicated their intent to make a submission. Although this group represents the bulk of all possible submitting States, undoubtedly other States will submit in the future. They could include some of the approximately 30 States Parties to the Convention

$5 \quad$ Id. Annex II, Article 3(1)(a).

$6 \quad$ Id. Article 76(8).

7 Annex II, Article 4 of the Convention calls upon coastal States to make submissions "within 10 years of the entry into force of [the] Convention for that State." Recognizing that the Commission did not begin its work until mid-1997 and had not adopted Scientific and Technical Guidelines until May 13, 1999, thereby creating "the basic documents concerning submissions in accordance with article 76, paragraph 8, of the Convention," the States Parties to the Convention decided to push the commencement date for the ten-year period up to May 13, 1999, thus creating a deadline of May 13, 2009 for any State Party for which the Convention had entered into force by May 13, 1999. Decision regarding the date of commencement of the ten-year period for making submissions to the Commission on the Limits of the Continental Shelf set out in article 4 of Annex II to the United Nations Convention on the Law of the Sea, SPLOS/72 (May 29, 2001).

8 A current list of submissions, recommendations and preliminary information documents along with all executive summaries of submissions, preliminary information documents, diplomatic notes reacting to submissions and other materials related to the Commission's work are available through the website of the CLCS http://www.un.org/Depts/los/clcs_new/clcs_home.htm (last visited May 24, 2010).

During the eighteenth meeting of the States Parties to the Convention it was decided that the submission deadline may be met by submitting "preliminary information documents indicative of the outer limits of the continental shelf beyond 200 nautical miles and a description of the status of preparation and intended date of making a submission." Decision regarding the workload of the Commission on the Limits of the Continental Shelf and the ability of States, particularly developing States, to fulfil the requirements of article 4 of annex II to the United Nations Convention on the Law of the Sea, as well as the decision contained in SPLOS/72, paragraph (a), SPLOS/183 (June 20, 2008), para. 1(a). 
for which the submission deadline has not yet passed. ${ }^{9}$ Also, non-Party States do not have access to the Commission process unless and until they accede to the Convention. It can be hoped that at least some non-Party States will accede and could then make claims before the Commission to extended shelf. ${ }^{10}$

To date, the area of shelf encompassed by submissions has topped 23 million square kilometers. ${ }^{11}$ Submissions of preliminary information documents made through 2009 indicate at least an additional 4 million square kilometers of continental shelf will eventually come under Commission review. ${ }^{12}$ In addition to the areas that will be added by new submitting States and as preliminary information documents transform into full-fledged submissions, more than half of the submissions made thus far are only "partial" submissions, implying that more area may be tacked on in future submissions by those submitting States. To a greater or lesser extent, depending on the submission, the Commission has pushed back against coastal State expansion by rejecting some of the scientific and technical bases on which submissions have been made. ${ }^{13}$ However, considering all of these factors, we can expect to see a net increase in the area coming under Commission review in the future.

9 Those States for which the Convention was not yet in force as of the modified commencement date created in SPLOS/72 are still subject to the original terms of Annex II, Article 4: ten years from date of entry into force for that State. Several of these States are likely to make submissions, including for example Madagascar, Morocco, Canada, Denmark, and Bangladesh.

10 A partial list of non-landlocked, non-Party States includes, for example, the United States of America and Venezuela.

11 Continental Shelf: The Last Maritime Zone, (Tina Schoolmeester \& Elaine Baker eds., UNEP/ GRID-Arendal 2009), at 28, available at $\mathrm{http}: / / \mathrm{www}$. unep.org/dewa/pdf/AoA/Continental_Shelf.pdf (last visited May 24, 2010).

The area encompassed in submissions has already far outstripped even recent estimates of the total area of continental shelf beyond 200 n.m. Prescott and Schofield estimated 14.9 million square kilometers of wide margin shelf around continents other than Australia. Victor Prescott \& Clive Schofield, The Maritime Political Boundaries of the World 187 ( $2 \mathrm{~d}$ ed. 2005).

12 Continental ShelF, supra note 11. Submissions of preliminary information documents often do not contain enough specific information to know the exact contours of the contemplated future submission.

13 The average return rate (i.e. area adopted after recommendations compared to area claimed in the submission) on the first seven recommendations that have been made public is approximately $97 \%$. Continental Shelf, supra note 11 . That is to say approximately $3 \%$ of the area of extended continental shelf claimed in those submissions has been deemed to be beyond the outer limit allowed under the terms of Article 76. In the most recent recommendations adopted by the Commission, Barbados appears to have been denied approximately 2,500 square kilometers or $5 \%$ of the area it claimed while the Commission rejected, in total, the submission made by the United Kingdom on behalf of Ascension Island. See Summary of Recommendations of the Commission on the Limits of the Continental Shelf in Regard to the Submission Made by Barbados on 8 May 2008 (Apr. 15, 2010); Summary of Recommendations of the Commission on the Limits of the Continental Shelf in Regard to the Submission made by the United Kingdom of Great Britain and Northern Ireland in Respect of Ascension Island on 9 May 2008 (Apr. 15, 2010). 
It follows that the greater the number of coastal States making submissions, and the more expansive the areas of continental shelf covered by those submissions, the greater the likelihood that claimed area will overlap with area claimed by a neighboring State. The effect has been the extension beyond 200 n.m. of existing boundary relationships and, in some instances, the creation of entirely new boundary relationships beyond 200 n.m. ${ }^{14}$ With few exceptions the submissions made thus far implicate one or more boundary relationship with a neighboring State and many of those relationships involve a dispute regarding overlapping claims to continental shelf that arises either from a sovereignty dispute over territory that forms the basis of the claim or from differing perspectives on the location of the maritime boundary that should separate overlapping areas of extended shelf. Of the approximately 23 million square kilometers encompassed by the first 51 submissions, ten percent of that area is included in two or more submissions and is therefore subject to overlapping claims. ${ }^{15}$

\section{ROLE OF THE COMMISSION ON THE LIMITS OF THE CONTINENTAL SHELF}

The Commission on the Limits of the Continental Shelf plays an important supervisory role in the otherwise unilateral process of establishing the outer limits of the continental shelf pursuant to Article 76 of the Convention. However, the Commission is not an arbiter of sovereignty or boundary disputes between coastal States and is not competent to consider the merits of lines of division between opposite or adjacent coastal States with overlapping claims. Above all, the Commission is a scientific and technical body tasked with a narrowly circumscribed review role. The Commission's focus and sole mandate is on the seaward outer limit of wide margin shelves claimed on the basis of the geologic, geomorphologic, hydrographic and geographic criteria provided for in Article 76 of the Convention and elaborated in the Commission's Scientific and Technical Guidelines. ${ }^{16}$ Nonetheless, as indicated above, land and maritime disputes are present in

14 For example, assuming Commission recommendations that conform with the submissions and likely future submissions of the following States, we can expect to see new boundary relationships that exist only beyond 200 n.m. between Russia and Denmark (Greenland) and Canada in the Arctic Ocean; France (Crozet Archipelago) and South Africa (Prince Edward Islands) in the Indian Ocean; New Zealand and Tonga; and perhaps several others in the south Pacific Ocean.

15 Continental Shelf, supra note 11.

16 See Scientific and Technical Guidelines of the Commission on the Limits of the Continental Shelf, CLCS/11 (May 13, 1999). 
many of the submissions before the Commission. This intersection between delineation of outer limits based on a review of scientific and technical data and delimitation of a lateral or opposite boundary based on legal arguments and political considerations creates an obvious tension. It is a tension that was anticipated by the drafters of the Convention and which is addressed in the text of the Convention and in the Commission's Rules of Procedure.

The text of Article 76 and related provisions attempts to insulate the Commission from concerns related to overlapping claims to continental shelf. Beginning with Article 76, the Convention is quite clear that "the provisions of [that] article are without prejudice to the question of delimitation of the continental shelf between States with opposite or adjacent coasts." 17 Annex II of the Convention further provides that "the actions of the Commission shall not prejudice matters relating to delimitation of boundaries between States with opposite or adjacent coasts." ${ }^{18}$ Rule 46 of the Commission's Rules of Procedure contains substantially similar language. ${ }^{19}$ Finally, Annex I to the Rules of Procedure emphasizes and expands this point: "The submissions made before the Commission and the recommendations approved by the Commission thereon shall not prejudice the position of States which are Parties to a land or maritime dispute." ${ }^{20}$

Taken at face value this language should eliminate the concerns of neighboring States with potentially overlapping claims and allow the Commission to conduct its review of the scientific and technical merits of a submission without regard to those outstanding disputes. Despite assurances that the work of the Commission will be without prejudice to their boundary positions, States appear wary of depending on this protection to safeguard their interests. The Commission process provides an opportunity for States to both maximize their outer limit as against the international community (the Area) and to maximize, promote or preserve territorial sovereignty and maritime boundary positions vis-a-vis neighboring or competing States. Many States have taken advantage of this opportunity to try to advance their interests. This self-serving but rational behavior, while not unexpected, has the effect of placing at the Commission's feet extremely contentious international disputes which the Commission is not in a position to resolve and has the potential to freeze the Commission's work.

171982 Law of the Sea Convention, Art. 76(10).

18 Id. Annex II, Art. 9.

19 Rules of Procedure of the Commission on the Limits of the Continental Shelf, CLCS/40/Rev.1 (Apr. 17, 2008), Rule 46(2).

20 Id. Annex I, para. 5(b). 
The Commission adopted Annex I to its Rules of Procedure in an attempt to balance, on the one hand, the interest in allowing the Commission to carry out its delineation work with, on the other hand, the interest in avoiding prejudice to Parties involved in unresolved disputes. Annex I-titled "Submissions in case of a dispute between States with opposite or adjacent coasts or in other cases of unresolved land or maritime disputes" - requires submitting States to inform the Commission of disputes and to assure the Commission that the submission will not prejudice such disputes. ${ }^{21}$ It then sets out a menu of options for submitting States involved in disputes which includes making a partial submission in order to avoid the area in dispute, ${ }^{22}$ or making a joint submission by two or more coastal States covering the area in dispute. ${ }^{23}$ Both of these approaches are designed to allow the Commission's review process to move forward despite the existence of a dispute: the former through coastal State self-restraint and the latter through cooperation. Where self-restraint or cooperation is not forthcoming, the Commission process can become stuck. Article 5(a) of Annex I reads: "In cases where a land or maritime dispute exists, the Commission shall not consider and qualify a submission made by any of the States concerned in the dispute. However, the Commission may consider one or more submissions in the areas under dispute with prior consent given by all States that are Parties to such a dispute." The practical result of this provision is that States are in a position to block Commission consideration of their neighbors' submissions. ${ }^{24}$

In addition to the requirement that the submitting State make the Commission aware of unresolved disputes, other States have the opportunity to inform the Commission of the existence of a dispute. The executive summary of each submission, which is made public soon after receipt of the full submission, must contain, among other things, charts and coordinates indicating the outer limit claimed by the submitting State. ${ }^{25}$ Information in the executive summary should be sufficient to allow other States to determine the location of the outer limit, the general basis of the claim, and whether the submission involves an area which they also claim. Other States may then react by written communication to the Commission

21 Id. Annex 1, para. 2.

22 Id. Annex 1, para. 3.

23 Id. Annex 1, para. 4.

24 For a thorough investigation of the impact other States can have on the CLCS process, see A.G.O. Elferink, The Establishment of Outer Limits of the Continental Shelf Beyond 200 N.m.s by the Coastal State: The Possibilities of Other States to have an Impact on the Process, 24 Int'1 J. Marine \& Coastal L. 535 (2009).

25 Scientific and Technical Guidelines, supra note 16, para. 9.1.4. 
via the Secretary-General of the United Nations. In addition to the executive summaries, these written communications are also made public. The majority of the submissions to date have elicited written communications from other States. These communications fall into three general categories: (1) communications expressing concerns about the scientific or technical basis of the outer limit, ${ }^{26}(2)$ communications expressing concerns related to undermining Article 4 of the Antarctic Treaty, ${ }^{27}$ and (3) communications related to unresolved disputes.

This last category is the largest of the three and it is the category of direct relevance to the topic at hand. These written communications manifest the intersection between the Commission's delineation process and the separate but intertwined boundary delimitation process. In communications related to unresolved disputes States have either (1) expressly consented to the Commission's consideration of the submission, notwithstanding the unresolved dispute, (2) reserved their position without giving express consent, or (3) expressly objected to Commission consideration of the submission. It is with the last of these possible reactions in mind that States must approach the submission process and the related boundary issues.

\section{APPROACHES TAKEN BY STATES}

States need not effect a complete delimitation of their extended continental shelf or resolve all outstanding disputes prior to making a submission to the Commission. In fact, in some instances it is only after full consideration of a submission that a State will know whether or to what extent boundaries need be agreed with neighbors. Nonetheless, if an unresolved dispute is

26 See, e.g., the reaction of the United States to the 2001 submission by the Russian Federation. Note verbale of the Representative of the United States of America to the United Nations to the UnderSecretary-General for Legal Affairs, United Nations (Feb. 28, 2002).

27 See, e.g., the reactions of the United States, Russia, Japan, the Netherlands, Germany, and India to Australia's 2004 submission. Diplomatic note of the United States Mission to the United Nations to the Secretary-General of the United Nations (Dec. 3, 2004); Note verbale No. 739/n of the Permanent Mission of the Russian Federation to the United Nations to the Secretary-General of the United Nations (Dec. 9, 2004); Note verbale No. SC/05/039 of the Permanent Mission of Japan to the United Nations to the Secretary-General of the United Nations (Jan. 19, 2005); Note verbale No. NYV/2005/690 of the Permanent Mission of the Netherlands to the United Nations to the United Nations Division for Ocean Affairs and the Law of the Sea (Mar. 31, 2005); Note verbale No. 88/2005 of the Permanent Mission of Germany to the United Nations to the United Nations Division for Ocean Affairs and the Law of the Sea (Apr. 5, 2005); Note verbale No. NY/ PM/443/1/98 of the Permanent Mission of India to the United Nations to the Secretary-General of the United Nations (July 5, 2005). 
present in the area encompassed by a submission, the submitting State must be cognizant of the possibility that its submission could be blocked ${ }^{28}$ With this in mind, States have engaged in behavior to avoid this outcome. The different approaches taken by States to address unresolved disputes are to (1) settle delimitations prior to making a submission; (2) make a partial submission that avoids unresolved disputes; (3) make a joint submission among several States, thereby internalizing any unresolved disputes within the group of submitting States; (4) make a separate submission after consultation with neighboring States in order to avoid objection; and (5) make a separate submission without assurances of no objection.

Before launching into a more complete description of these approaches, several general comments are in order. First, a single submission may embody more than one approach. A State may have an agreed boundary with one neighboring State but may need to take a different approach in the same submission with respect to another neighbor. ${ }^{29}$ Second, a significant amount of time can pass between lodging a submission and receiving recommendations from the Commission. ${ }^{30}$ Relationships with neighboring

28 After lodging a submission, the submitting State is scheduled to present the submission to the Commission. This may happen not less than three months after the publication of a submitting State's executive summary in order that other States may react to the submission in writing. When the Commission hears the submitting State's presentation it will also have before it the reactions of other States, including, any objections raised by neighbors. Where there have been objections, the Commission has used the following rather cryptic language: "Taking into account these notes verbales and the presentation made by the delegation, the Commission decided to defer further consideration of the submission and the notes verbales until such time as the submission is next in line for consideration as queued in the order in which it was received. The Commission took this decision in order to take into consideration any further developments that might occur throughout the intervening period during which States may wish to take advantage of the avenues available to them including provisional arrangements of a practical nature as contained in annex I to its rules of procedure." Statement by the Chairman of the Commission on the Limits of the Continental Shelf on the progress of work in the Commission, CLCS/64 (Oct. 1, 2009), paras. 40, 46, 52, 71, 92, 106 regarding, respectively, the deferral of submissions by Myanmar, United Kingdom, Ireland, Fiji, Malaysia/Viet Nam, and Viet Nam. Deferral at this stage of the process is in lieu of forming a subcommission: the necessary next step on the winding road toward Commission endorsement.

29 For example, Australia succeeded in delimiting boundaries with France, New Zealand and the Solomon Islands prior to its submission. Continental Shelf Submission of Australia; Executive Summary (Nov. 15, 2004). However, at the time of submission there was an outstanding delimitation issue in the Three Kings Ridge Region. While agreeing with the principles used to measure Australia's outer limit in the undelimited area of that Region, the Commission noted that "the establishment of the final outer limit of the continental shelf of Australia in this Region may depend on delimitation between States." Summary of the Recommendations of the Commission on the Limits of the Continental Shelf (CLCS) in regard to the Submission Made by Australia on 15 November 2004 (Apr. 9, 2008), para. 117.

30 One assessment indicates that the Commission will not finish its review of Cuba's Submission - the 51st - until 2030. At the nineteenth meeting of the States Parties, the Chairman of the Commission "projected a schedule for consideration of the submissions received to date and for the adoption of 
States could change during that time increasing or decreasing the tension between delimitation and outer limit delineation. Concurrently, submissions may also be changed to reflect new developments. ${ }^{31}$ Third, it should be noted that the bulk of the Commission process is conducted in private. The only written documents that are made public are the executive summaries of the submissions, written reactions submitted by other States, and - eventually - summaries of the Commission's recommendations. ${ }^{32}$ The other parts of the submissions and the full recommendations are not made public and meetings between the Commission (or its sub-commissions) and submitting States - meetings in which it appears that a substantial dialogue may occur on a number of topics related to the submission, including, presumably, the topic of unresolved disputes with neighbors-are held in private. ${ }^{33}$ Even with relatively little information, it is still possible to differentiate the following five approaches taken by States and to find in the State practice to date some examples of each. ${ }^{34}$

recommendations, based on current working practice of the Commission and availability of its members in the work of the subcommissions. According to that projection, the recommendations regarding the submission made by Cuba, the last submission received by the Commission to date, would be adopted in or about 2030." Report of the nineteenth Meeting of States Parties, SPLOS/203 (July 24, 2009), para. 83, available at $\mathrm{http}: / / \mathrm{www} . u n . o r g /$ Depts/los/meeting_States_Parties/SPLOS_ documents.htm (last visited May 24, 2010).

31 For example, France, requested "the Commission to refrain from consideration of the portion of the submission related to the area in the southeastern part of New Caledonia" after receiving Vanuatu's reaction to the French submission in regard to New Caledonia. Letter No. 547/SGMER of the French Secretary-General of the Sea to the Chairperson of the Commission on the Limits of the Continental Shelf (July 18, 2007). In that written communication, Vanuatu - referencing the sovereignty dispute over Matthew and Hunter Islands - asked the Commission to consider the territorial dispute and related claims to maritime area "very seriously." Letter from Vanuatu Ministry of Foreign Affairs and External Trade to the Chairman of the Commission on the Limits of the Continental Shelf (July 11, 2007). See also, Summary of Recommendations of the Commission on the Limits of the Continental Shelf in regard to the Submission made by France in respect of French Guiana and New Caledonia Regions on 22 May 2007 (Sept. 2, 2009), paras. 43-44.

32 To date only nine summary recommendations have been made public: Australia, Ireland (Porcupine Abyssal Plain), New Zealand, France/Ireland/Spain/United Kingdom (Celtic Sea and Bay of Biscay), Norway (North East Atlantic and Arctic), France (French Guiana and New Caledonia), Mexico (Western Gulf of Mexico), Barbados, and the United Kingdom (Ascension Island). Recommendations have been adopted but not made public for the submissions of the Russian Federation and Brazil.

33 The Commission process, if not entirely opaque, is, at the very least, Byzantine. For a useful road map to this intricate and complex process the reader is directed to the Commission's Rules of Procedure, Annex III Modus operandi for the consideration of a submission made to the Commission on the Limits of the Continental Shelf available on the CLCS website.

34 In a few instances the geography alone is such that a submission does not implicate any international boundary relationship. That is, no other State may conceivably encompass within its outer limit any of the area encompassed in these rare submissions. This requires a combination of a wide margin and a relatively isolated position on the world map. The United Kingdom's submission on behalf of its territory of Ascension Island provides one, rare example. 


\section{A Delimitation prior to submission}

States may avoid unresolved delimitation issues in submissions before the CLCS by resolving disputes in advance of the submission. However, no boundaries beyond 200 n.m. have been settled by adjudication or arbitration and only a small handful have been settled by agreement at the time of this writing. ${ }^{35}$ Some of these delimitations may have been carried out with the submission process specifically in mind. It has been reported that the submission process was the main motivator for Australia and New Zealand to complete the delimitation of their boundaries beyond 200 n.m. ${ }^{36}$

Another example of cooperation resulting in delimitations in anticipation of submission was demonstrated by the three States - Iceland, Norway, and Denmark (Faroes) - with overlapping claims to extended continental shelf in the southern part of the so called Banana Hole. Before any of the three States lodged a submission, they negotiated agreed minutes that established the three boundaries among them, identified their shared tripoint, and secured an agreement to not object to Commission consideration of subsequent submissions in the area. ${ }^{37}$ The three States have since made submissions claiming extended continental shelf in the Banana Hole. ${ }^{38}$ Notably, the outer limits in these submissions do not correspond to the agreed boundaries, instead they stretch beyond them. The States recognized that, in addition to agreeing the boundaries that would divide overlapping areas of extended continental shelf, they must also demonstrate an entitlement to those areas of shelf under the terms of the Convention in the Commission process. The agreed minutes provide for the event that one or more of the States is unable to demonstrate "that the area of its continental shelf beyond 200 nautical miles corresponds in size, as a minimum, to the area that falls

35 See, e.g., Report Numbers 1-5(2) (Mexico-United States), 2-13(3) (Trinidad and Tobago-Venezuela), 5-1 (Australia-France (New Caledonia)), 5-4 (Australia-Solomon Islands), 5-26 (Australia-New Zealand), 6-1 (Australia (Heard and McDonald Islands)-France (Kerguelen Islands)), 9-7 (IrelandUnited Kingdom), and 9-26 (Denmark-Iceland-Norway).

36 See, e.g., Report Number 5-26 (Australia-New Zealand), at 3760 ("the impetus for undertaking and completing the process was provided by the impending submission, by both countries, of their proposed continental shelf coordinates to the [Commission]").

37 See Report Number 9-26 (Denmark-Iceland-Norway) in this volume.

38 See Submission of Norway in respect of areas in the Arctic Ocean, the Barents Sea and the Norwegian Sea; Executive Summary (Nov. 27, 2006); The Icelandic Continental Shelf: Partial Submission to the Commission on the Limits of the Continental Shelf pursuant to article 76, paragraph 8 of the United Nations Convention on the Law of the Sea in respect of the Aegir Basin area and Reykjanes Ridge; Executive Summary (Apr. 29, 2009); Partial Submission of the Government of the Kingdom of Denmark together with the Government of the Faroes to the Commission on the Limits of the Continental Shelf; Executive Summary (Apr. 29, 2009). 
to the same State according" to the agreed boundaries. ${ }^{39}$ If this were to occur, the boundaries would be adjusted on the basis of previously agreed terms also found in the minutes.

In 2000 the United States and Mexico settled their boundary beyond 200 n.m. in the "western gap" of the Gulf of Mexico. ${ }^{40}$ There is no evidence that this delimitation was carried out in anticipation of submissions to the Commission. Nonetheless, in 2007 Mexico lodged a submission regarding this same area and used the negotiated boundary as its outer limit. ${ }^{41}$ This is a different approach to that used by the three States around the Banana Hole. Unlike the agreed minutes among Denmark, Norway and Iceland, the agreement between the United States and Mexico does not contemplate adjustments to the boundary on the basis of demonstrated entitlement to the respective areas of extended continental shelf under international law. This may reflect a high level of confidence that the States can both demonstrate entitlement up to the agreed line. This has certainly turned out to be true for Mexico. Recommendations were quickly forthcoming endorsing in full Mexico's claimed outer limit. Mexico has since accepted the recommendations and established its outer limit on the basis of those recommendations in accordance with Article 76. Mexico is now one of only a small number of States to have taken the Commission process through to this final and binding step. The complete delimitation of the area under consideration is one factor that allowed the Mexican Submission to move quickly through the process.

It can be expected that some boundaries will be agreed during the Commission's consideration of related submissions. The review process can be quite drawn out giving Parties to a dispute some time to reach agreement. For example, Russia made its initial submission in 2001 and received recommendations from the Commission in 2002. Those recommendations are not public and a summary of the recommendations has also not yet been made public. From what information is available it is to be assumed that Russia accepted some but not all of the recommendations and is now in the process of revising its submission. In the meantime, press reports indicate that Russia and Norway have reached agreement on their boundary in the Barents Sea. At the current pace the Commission is not expected to adopt recommendations on Cuba's Submission-the 51st and last in

39 Report Number 9-26 (Denmark-Iceland-Norway) in this volume.

40 Report Number 1-5(2) (Mexico-United States).

41 A Partial Submission of Data and Information on the Outer Limits of the Continental Shelf of the United Mexican States pursuant to Part VI of and Annex II to the United Nations Convention on the Law of the Sea (Dec. 13, 2007). 
line - until 2030, giving the United States, Mexico, and Cuba twenty more years to complete their respective boundaries in their shared area in the "eastern gap" of the Gulf of Mexico.

It is expected that if States reach agreement on boundaries related to their submission while the submission is still before the Commission, they will update their submissions accordingly. ${ }^{42}$ For now, delimited boundaries beyond 200 n.m. remain the exception.

\section{B Partial submission}

Where disputes have not been resolved in advance of a submission, some submitting States have elected to make partial submissions intended to avoid areas in dispute. The Commission provides for this approach in Annex I, paragraph 3 which reads in part: "A submission may be made by a coastal State for a portion of its continental shelf in order not to prejudice questions relating to the delimitation of boundaries between States in any other portion or portions of the continental shelf for which a submission may be made later." More than half of the 51 submissions have been partial submissions ${ }^{43}$ Other reasons exist for making partial submissions,${ }^{44}$ but avoiding areas in dispute is the reason given in several of the executive summaries. Ireland, in one of the earliest submissions, noted "ongoing discussions with neighbouring States" and elected to make a partial submission "in order not to prejudice unresolved questions relating to the delimitation of boundaries between Ireland and some of its neighbours in other portions of the extended continental shelf claimed by Ireland." ${ }^{45}$ In a more recent submission, the Philippines explained that its partial submission

42 See, e.g., the reporting on Commission recommendations to Russia regarding future entry into force of boundaries. "In the case of the Barents and Bering seas, the Commission recommended to the Russian Federation, upon entry into force of the maritime boundary delimitation agreements with Norway in the Barents Sea, and with the United States of America in the Bering Sea, to transmit to the Commission the charts and coordinates of the delimitation lines as they would represent the outer limits of the continental shelf of the Russian Federation extending beyond 200 nautical miles in the Barents Sea and the Bering Sea respectively." Oceans and the law of the sea: Report of the Secretary-General, A/57/57/Add.1 (Oct. 8, 2002), para. 39.

43 Continental Shelf, supra note 11, at 20.

44 States with several, non-contiguous parcels of territory, such as France, the United Kingdom, and South Africa, have made multiple, partial submissions for different parcels of territory. For other States partial submissions have been necessary where preparation for a complete submission has not been politically or technically possible by the submission deadline.

45 Submission to the Commission on the Limits of the Continental Shelf pursuant to Article 76, paragraph 8 of the United Nations Convention on the Law of the Sea 1982 in respect of the area abutting the Porcupine Abyssal Plain; Executive Summary (May 25, 2005), at 4. 
relating only to the Benham Rise was made "as a gesture of good faith... to avoid creating or provoking maritime boundary disputes where there are none, or exacerbating them where they may exist." ${ }^{46}$

For the submitting State this approach has the advantage of removing one possible roadblock to Commission consideration. The approach requires only minimal communication or coordination with neighbors: only enough to ascertain the spatial extent of their claims in the area under consideration. A potential drawback of this approach is that it has the submitting State asserting less than its maximum claim to area before an international body. While these omissions have no direct legal effect on the claims of the submitting State and could in fact contribute to regional peace and stability, this self restraint could also, depending on the domestic climate, be politically unpalatable if it appears to leave the submitting State open to criticism by neighbors in future negotiations or other proceedings.

\section{Joint submission}

Annex I also refers to the possibility of joint submissions by two or more coastal States "without regard to the delimitation of boundaries between those States. ${ }^{977}$ Five of the 51 submissions have been joint submissions. ${ }^{48}$

In the first joint submission, and the only one for which recommendations have been adopted, the spokesperson for the four submitting States - France, Ireland, Spain, and the United Kingdom - noted "that all four coastal States could have made potentially overlapping, separate submissions. However, they considered it more appropriate to avail themselves of the possibility of making a joint submission since, upon the issuance of recommendations by the Commission, the four coastal States would be able to establish the outer limit of their continental shelf in the region prior to

46 A Partial Submission of Data and Information on the Outer Limits of the Continental Shelf of the Republic of the Philippines Pursuant to Article 76(8) of the United Nations Convention on the Law of the Sea; Executive Summary (Apr. 8, 2009) at 11.

47 Rules of Procedure, supra note 19, Annex I, para. 4.

48 See the Joint Submission by France, Ireland, Spain and the United Kingdom of Great Britain and Northern Ireland (Celtic Sea and Bay of Biscay) (May 19, 2006); Joint Submission by the Republic of Mauritius and the Republic of Seychelles (Mascarene Plateau) (Dec 1, 2008); Joint Submission by the Federated States of Micronesia, Papua New Guinea and Solomon Islands (Ontong Java Plateau) (May 5, 2009); Joint Submission by Malaysia and Viet Nam (southern South China Sea) (May 6, 2009); and the Joint Submission by France and South Africa (Crozet Archipelago and Prince Edward Islands) (May 6, 2009).

Several preliminary information documents have also been submitted jointly by two or more States. 
its delimitation among themselves."49 This submission was both joint and partial, so while it encompassed areas claimed by more than one submitting State, the scope was limited to avoid area claimed by non-submitting States. The result of this approach is that the four States have moved quickly through the Commission process, ascertained the size and scope of their shared area, and may now set about splitting it up through the usual bilateral processes and at their leisure.

This will not necessarily be the outcome in all joint submissions. The joint submission by Malaysia and Viet Nam in the southern part of the South China Sea might have allayed Commission concerns with respect to unresolved disputes between the two submitting States, but because it did not include all interested Parties, it has been blocked by neighbors. This submission elicited an immediate reaction from China, invoking Annex I, Article 5(a), and "request[ing] the Commission not to consider the Joint Submission." 50 The Philippines soon followed suit "request[ing] the Commission to refrain from considering the aforementioned [submission], unless and until after the Parties have discussed and resolved their disputes." ${ }^{51}$ The disputes referred to are of the most contentious and intractable kind involving conflicting claims to sovereignty over insular territory in the South China Sea and parts of the island of Borneo and overlapping claims to the associated maritime areas. These disputes are long-standing, multi-State, and involve valuable resources in addition to other strategic considerations. The fact of cooperation in this environment between Malaysia and Viet Nam is noteworthy, but was not sufficient to overcome conflicting positions held by other States. The Joint Submission was presented to the Commission by the submitting State representatives in August 2009 at which time the Commission also considered the flurry of written communications it had received from the submitting States, China, and the Philippines. At that meeting "the Commission decided to defer further consideration of the submission and the notes verbale until such time as the submission is next in line for consideration." 52 One would expect that until China and the Philippines withdraw their objections or join the submission, consideration of this joint submission will continue to be deferred.

49 Statement by the Chairman of the Commission on the Limits of the Continental Shelf on the progress of work in the Commission, CLCS/62 (Apr. 20, 2009), para. 12.

50 Note verbale No. CML/17/2009 of Permanent Mission of China to the United Nations to the Secretary-General of the United Nations, (May 7, 2009).

51 Note verbale No. 000819 of the Permanent Mission of the Philippines to the Secretary-General of the United Nations (Aug. 4, 2009).

52 Statement by the Chairman CLCS/64, supra note 28, para. 92. 
Joint submissions require significant cooperation and forethought. This will increase some transaction costs, but may result in efficiencies as well..$^{53}$ In the right circumstances the effort can remove unresolved disputes from the equation. However, as demonstrated above, without all necessary Parties a joint submission may still fail to overcome the obstacle presented by uncooperative neighboring States willing to invoke unresolved disputes to block Commission consideration.

\section{Separate submissions: cooperation}

The preponderance of all submissions and preliminary information documents are lodged separately by single States. As noted above, many of these separate submissions are only partial submissions, and some of those submissions are made in that form expressly to avoid unresolved disputes. Very few of these separate submissions involve areas of extended shelf that are already fully delimited by agreement with neighboring States. Mexico's submission and the submissions related to the Banana Hole provide examples of this small subset. This leaves a large group of separate submissions that are not partial and which cover areas subject to as yet unresolved delimitations. States making separate submissions under these conditions take one of two general approaches to unresolved disputes. The first involves presubmission cooperation that might include data exchange, an exchange of views on extended shelf boundary positions, the beginnings of the negotiation of those boundaries, or securing some form of pre-submission agreement from neighbors not to object. The second approach involves lodging a separate submission that will create areas of overlap but without pre-submission cooperation and despite the lack of a "no objection" agreement. The first approach is addressed here, the second in the following section.

Cooperation that does not result in an agreed boundary or amount to a joint submission can be difficult to detect or confirm. In some instances such cooperation is made apparent in the executive summaries and related written communications. In others it requires some speculation. Moreover, cooperation can take many forms.

53 Murphy lists several advantages to joint submissions including: overcoming unresolved boundaries, combined datasets, pooled expertise and division of labor. See Alain Murphy, Coordinated, Harmonized or Joint Submissions to the Commission on the Limits of the Continental Shelf, presented at 5th ABLOS Conference, Difficulties in Implementing the Provisions of UNCLOS, Monaco, 15-17 October 2008, available at http://www.gmat.unsw.edu.au/ablos/ABLOS08Folder/ ablos08_papers.htm (last visited May 21, 2010). 
In a relatively well-documented example, several ECOWAS member States including Benin, Cote d'Ivoire, Ghana, Nigeria, and Togo met in February 2009 and agreed that "issues of the limit of adjacent/opposite boundaries shall continue to be discussed" and that "member States would therefore write "no objection note" to the submission of their neighboring States." ${ }^{44}$ With the exception of the recent agreement between Benin and Nigeria, no boundaries have been agreed among these five States either within or beyond 200 n.m. ${ }^{55}$ Since the February 2009 multilateral "no objection" agreement, Ghana, Nigeria and Cote d'Ivoire have lodged submissions with the Commission and Togo and Benin have submitted separate and joint preliminary information documents. The areas claimed by Benin, Ghana, Nigeria, and Togo all overlap to some degree, but, presumably on the basis of the no prejudice language of the Convention and the Agreement of February 2009, none of the States has objected to consideration by the Commission.

In the complex political geography of northeastern South America multiple submissions and preliminary information documents have been lodged with the Commission including submissions by Brazil, France (French Guiana), Barbados, Suriname, and Trinidad and Tobago. Guyana has submitted preliminary information documents and Venezuela - non-Party to the Convention - has indicated a claim to extended shelf in an area included in other submissions. ${ }^{56}$ Here, several of the boundaries within 200 n.m. and one delimiting areas beyond 200 n.m. have been settled by negotiation. ${ }^{57}$ Two have been the subject of recent arbitration. ${ }^{58}$ Unresolved disputes in the region include a long-standing sovereignty dispute between Venezuela and Guyana to territory that includes coastal area that could influence maritime entitlements and boundaries. Some of the boundaries within and most of the boundaries beyond 200 n.m. are also undelimited. In addition, there is significant disagreement between Trinidad and Tobago and Barbados

54 Minutes of Experts Meeting of ECOWAS member States on the Outer Limits of the Continental Shelf, Accra, 24-26 February 2009, Appendix A, quoted in Submission by Government of the Republic of Ghana for the Establishment of the Outer Limits of the Continental Shelf of Ghana pursuant to Article 76, paragraph 8 of the United Nations Convention on the Law of the Sea; Executive Summary (Apr. 28, 2009), para. 5.2.

55 See Report Number 4-14 (Benin-Nigeria) in this volume.

56 Note verbale No. 00766 of the Ministry of the People's Power for Foreign Affairs of Venezuela to the Secretary-General of the United Nations (Sept. 9 2008) ("Venezuela... has rights over the continental shelf in the area referred to in the summary of Barbados as the "southern area'.")

57 See Report Numbers 2-13(3) (Trinidad and Tobago-Venezuela), 3-3 (Brazil-France (French Guiana)), and 2-27 (Barbados-Guyana).

58 See Report Numbers 2-26 (Barbados-Trinidad and Tobago), 3-10 (Guyana-Suriname). 
about the effect of their boundary award on entitlement to extended continental shelf.

Considering the many outstanding issues in this region it is not surprising that the submissions and preliminary information documents lodged to date indicate several areas of significant overlap. Despite these overlaps and in the absence of a regional multilateral "no objection" agreement, no neighboring State has objected to Commission consideration of submissions in this region. This level of cooperation appears to have been accomplished through a network of bilateral consultations and agreements to not object. For example, Suriname indicates that it held consultations with all of its neighbors, including France, Guyana, Barbados, Trinidad and Tobago, and Venezuela and secured agreements from all of them not to object to Suriname's submission..$^{59}$ Written communications from Barbados, France, and Trinidad and Tobago confirm some of these agreements. Barbados refers to no objection agreements with Suriname, Guyana, and France. ${ }^{60}$ Trinidad and Tobago refers to consultations with and agreements to not object from Venezuela, Suriname, and Guyana. ${ }^{61}$

Less complex examples of pre-submission consultation and apparent cooperation are available. South Africa noted an exchange of letters with Madagascar agreeing that "their respective submissions may be considered by the Commission on the understanding that this shall not prejudice future delimitation." ${ }^{62}$ New Zealand noted, with respect to its unresolved delimitation with Tonga, that it "has made extensive efforts to resolve the boundary both prior to and since presenting its submission and that negotiations between New Zealand and Tonga remain ongoing." ${ }^{63}$ In its submission, Kenya refers to a memorandum of understanding between Kenya and Somalia "granting each other no objection in respect of submissions." ${ }^{4}$

59 Government of the Republic of Suriname Submission on the Outer Limits of the Continental Shelf; Executive Summary (Dec. 5, 2008), at 2.

60 Government of Barbados Continental Shelf Submission; Executive Summary (May 8, 2008), para. 1.4.1.

61 Submission to the Commission on the Limits of the Continental Shelf pursuant to the Article 76, paragraph 8 of the United Nations Convention on the Law of the Sea, Republic of Trinidad and Tobago; Executive Summary (May 12, 2009), at 16.

62 Republic of South Africa Partial Submission to the Commission on the Limits of the Continental Shelf pursuant to Article 76, paragraph 8 of the United Nations Convention on the Law of the Sea 1982 in respect of the area of the South African Mainland; Executive Summary (May 5, 2009), at 2-3.

63 Note verbale No. $07 / 08 / 41$ of the Permanent Mission of New Zealand to the United Nations to the Secretary-General of the United Nations (July 31, 2008).

64 Republic of Kenya Submission on the Continental Shelf beyond 200 n.m.s to the Commission on the Limits of the Continental Shelf in accordance with requirement of the United Nations Convention on the Law of the Sea; Executive Summary (May 6, 2009), para 7.3 The Transitional Federal 
Norway, in its written reaction to the 2001 Russian submission, noted that the undelimited boundary between Norway and Russia in the Barents Sea was "the object of ongoing consultations" and gave its consent "to an examination by the Commission of the Russian submission." 65 The common thread running through these examples is the avoidance of objection by neighboring States through prior consultation despite the existence of significant overlapping claims to areas of extended continental shelf.

\section{E Separate submission: conflict}

Separate submissions made to areas claimed by neighbors and without prior consultation or assurances of no objection are at risk of being blocked by any neighboring State that objects to Commission consideration under Annex I, para 5(a) ${ }^{66}$ As demonstrated above, even joint submissions are vulnerable to this reaction. In addition to the joint submission by Malaysia and Viet Nam in the South China Sea, several separate submissions are currently on hold as a result of objections.

Overlapping areas of extended continental shelf in the Bay of Bengal are subject to the separate submissions by Myanmar, Sri Lanka, and India. Despite significant overlap among these claims, these three submitting States have not objected to the submissions by the other two. However, Bangladesh - the fourth coastal State on the Bay of Bengal - has not yet lodged its own submission, but it has objected to the submissions of India and Myanmar. ${ }^{67}$ In written reactions to both submissions, Bangladesh invoked Annex I, para. 5(a), noted unresolved delimitations with both neighbors, and objected to Commission consideration of the submissions. ${ }^{68}$

Parliament of Somalia subsequently refused to ratify the memorandum of understanding, but Somalia has not submitted a written communication objecting to consideration of Kenya's submission by the Commission. See Note verbale No. OPM/IC/00./016/09 from the Prime Minister of Somalia to the Secretary-General of the United Nations (Oct. 10, 2009).

65 Note verbale of the Permanent Mission of Norway to the United Nations to the Secretary-General of the United Nations (Mar. 20, 2002).

66 A lack of prior consultation does not necessarily result in objections from neighbors anymore than prior consultation can guaranty protection against objections. There are instances of possible overlap in which no apparent pre-submission consultations have been carried out and in which neighboring States have also not objected. See, e.g., the French Submission in respect of La Reunion Island, the undelimited boundary with Madagascar beyond 200 n.m., and the apparent lack of reaction from Madagascar.

67 Bangladesh has until 2011 to make its submission or to lodge preliminary information documents.

68 Note verbale No. PMBNY-UNCLOS/2009 of the Permanent Mission of Bangladesh to the United Nations to the Secretary-General of the United Nations (Oct. 29, 2009); Note verbale No. 
During its twenty-fourth session held from August 10 to September 11, 2009, the Commission, taking note of the views expressed by Bangladesh in its note verbale, "decided to defer further consideration of the [Myanamar] submission." ${ }^{69}$ A month later, on October 8, 2009, Bangladesh instituted arbitral proceedings against both Myanmar and India pursuant to Annex VII of the Convention, asking separate tribunals to delimit its territorial sea, exclusive economic zone, and continental shelf boundaries with its two neighbors. ${ }^{70}$ Although India was initially scheduled to present its submission during the twenty-fifth session of the Commission in March and April 2010, for reasons that are undoubtedly related to the Bangladesh objection and the ongoing delimitation case, India has not been given the opportunity to present its submission to the Commission.

The United Kingdom and Argentina have both lodged claims to extended shelf on the basis of conflicting claims to sovereignty over territory in the South Atlantic Ocean. ${ }^{71}$ The United Kingdom reacted to Argentina's Submission writing that it "rejects those parts of Argentina's submission which claim rights to the seabed and subsoil of the submarine areas appurtenant to the Falkland Islands, South Georgia and the South Sandwich Islands, and requests that the Commission does not examine those parts of the Argentine submission." "72 Likewise, Argentina reacted to the United Kingdom Submission writing that it "categorically rejects the British submission and expressly requests that the Commission...neither consider nor qualify it." ${ }^{\text {73 }}$ The Commission took note of some of the reactions directed at the Argentine Submission that were related to Antarctica. There is no evidence that the Commission considered the British note verbale regarding the Argentine Submission, however, this submission appears

PMBNY-UNCLOS/2009 of the Permanent Mission of Bangladesh to the United Nations to the Secretary-General of the United Nations regarding Myanmar (July 23, 2009).

69 Statement by the Chairman CLCS/64, supra note 28, para. 40.

70 See Report Numbers 6-23 and 6-24 in this volume. The Parties to the Bangladesh/Myanmar arbitration issued parallel declarations accepting the jurisdiction of the International Tribunal on the Law of the Sea. That case is now before ITLOS. The Bangladesh/India case is in its early stages before an Annex VII tribunal.

71 See Outer Limit of the Continental Shelf, Argentine Submission; Executive Summary (Apr. 21, 2009); Submission to the Commission on the Limits of the Continental Shelf pursuant to Article 76, paragraph 8 of the United Nations Convention on the Law of the Sea 1982 in respect of the Falkland Islands, and of South Georgia and the South Sandwich Islands; Executive Summary (May 11, 2009).

72 Note verbale No. 84/09 of the Permanent Mission of the United Kingdom to the Secretary-General of the United Nations (Aug. 6, 2009).

73 Note verbale No. 290/09/600 of the Permanent Mission of Argentina to the United Nations to the Secretary-General of the United Nations (Aug. 20, 2009). 
to be on hold. ${ }^{74}$ The fate of the British Submission is clearer: "the Commission decided that, in accordance with its rules of procedure, it was not in a position to consider and qualify the submission." 75

Several other submissions have suffered a similar fate. For example, the separate submissions by Ireland and the United Kingdom in respect of the Hatton-Rockall Area - an area in which these two States have settled their boundary by agreement - elicited express objections from the neighboring States of Denmark and Iceland. ${ }^{76}$ Vanuatu expressed an objection to Fiji's Submission on the basis of Vanuatu's claims to Matthew and Hunter Islands. ${ }^{77}$ China and the Philippines have both asked the Commission not to consider Viet Nam's separate Submission in the South China Sea. ${ }^{78}$ The Philippines has also asked the Commission to refrain from considering Palau's Submission. ${ }^{79}$ The Commission has deferred consideration of the submissions by Ireland, the United Kingdom, Fiji, and Viet Nam. ${ }^{80}$ Palau's Submission has not yet been presented to the Commission.

\section{CONCLUSION}

The Commission process under the terms of the Convention and the Commission's Rules of Procedure has attempted to strike a workable balance between the establishment of the outer limits of extended continental shelf and the process of agreeing or adjudicating the lines that divide areas of shelf claimed by two or more States. The language in the Convention and related texts that provides that the Commission process is without

74 See Statement by the Chairperson of the Commission on the Limits of the Continental Shelf on the progress of work in the Commission, CLCS/66 (Apr. 30, 2010), para. 37.

75 Id. para. 60.

76 Note verbale No. FNY09050022/97.B.512 of the Permanent Mission of Iceland to the United Nations to the Secretary-General of the United Nations (May 27, 2009); Note verbale No. 119.N.8 of the Permanent Mission of Denmark to the United Nations to the Secretary-General of the United Nations (May 27, 2009); Note verbale No. FNY09050023/97.B.512 of the Permanent Mission of Iceland to the United Nations to the Secretary-General of the United Nations (May 27, 2009); Note verbale No. 119.N.8 of the Permanent Mission of Denmark to the United Nations to the SecretaryGeneral of the United Nations (May 27, 2009).

77 Note verbale of the Permanent Mission of Vanuatu to the United Nations to the Secretary-General of the United Nations (Aug. 12, 2009).

78 Note verbale No. CML/18/2009 of the Permanent Mission of China to the United Nations to the Secretary-General of the United Nations (May 7, 2009); Note verbale No. 000818 of the Permanent Mission of the Philippines to the United Nations to the Secretary-General of the United Nations (Aug. 4, 2009).

79 Note verbale No. 000820 of the Permanent Mission of the Philippines to the United Nations to the Secretary-General of the United Nations (Aug. 4, 2009).

80 Statement by the Chairman CLCS/64, supra note 28. 
prejudice to delimitation and sovereignty disputes appears to have allowed the process of reviewing data related to outer limit claims to move forward without significant interference from neighboring States. However, in some instances neighboring States have-despite this language-objected to Commission consideration of submissions that contain competing claims and have been able to freeze the Commission process with respect to those submissions.

Submitting States are aware of this possibility and have made efforts to forestall interference by agreeing their boundaries before submitting, making a partial submission that avoids boundary issues, making a joint submission, or reaching an agreement to disagree and, importantly, to refrain from objection. In a handful of highly contentious situations, these efforts - to the extent they have been made at all - have proved insufficient and the clearly non-prejudicial nature of the Commission process has proved unconvincing, resulting in deferred consideration of these submissions.

Deferred consideration of a submission is a bad result for the submitting State. Deferral represents the total failure of one of the two main goals in the extended continental shelf game: completing the Commission process with favorable recommendations for establishing an outer limit. And it may do nothing to increase the likelihood of success with respect to the other goal: maximizing area of extended continental shelf. For States that have not yet submitted, attempts can be made to avoid this bad result using the approaches discussed in this essay. For States that find themselves in Commission purgatory, there are opportunities for atonement. When deferring a submission for future consideration the Commission has noted that it is taking this step "in order to take into consideration any further developments that might occur throughout the intervening period during which States may wish to take advantage of the avenues available to them including provisional arrangements of a practical nature as contained in annex I to its rules of procedure." ${ }^{\prime 1}$ Considering the rather extended time line over which the Commission process is likely to unfold, this will give submitting States and their objecting neighbors ample time to apply more successful approaches to the unresolved disputes embedded in their submissions.

$81 I d$. paras. 40, 46, 52, 71, 92, 106. 